\title{
Benign Lung PEComa
}

National Cancer Institute

\section{Source}

National Cancer Institute. Benign Lung PEComa. NCI Thesaurus. Code C142784.

A benign lung tumor that arises from perivascular epithelioid cells (PECS). 